\author{
همبستخى نمايه گرمابى سليانينف با نرخ تبخير و تعرق نياز آبى برخى محصولات \\ كشاورزى در ايستخاههاى هواشناسى منتخب ايران \\ على اكبر سبزىيرور *، سجاد ابراهيمزاده و مهرانه خدامراديور'

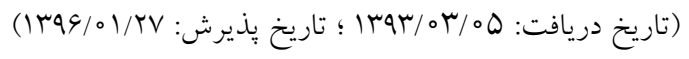

جكيده

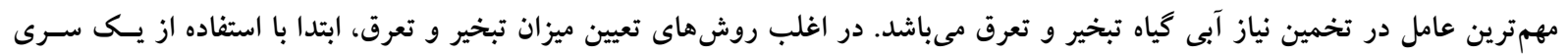

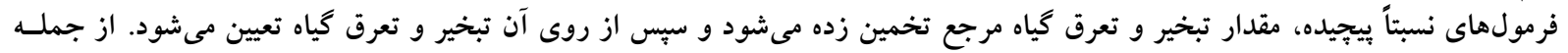

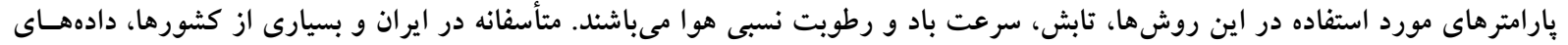

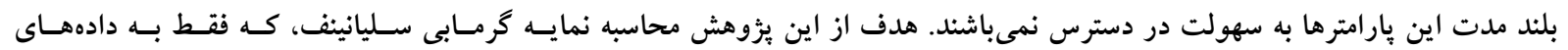

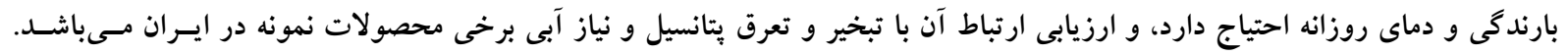

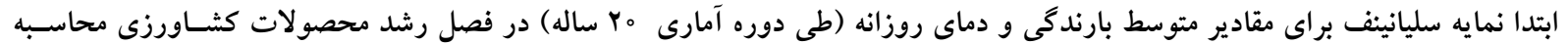

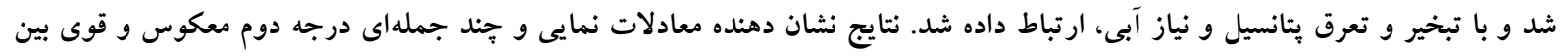

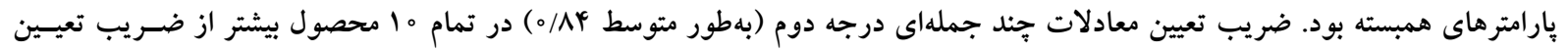

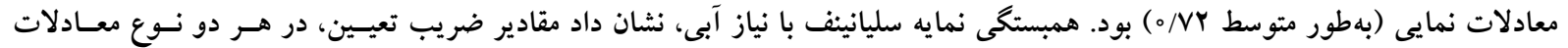

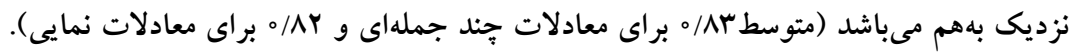

وازمهاى كليدى: نيازآبى، تبخير و تعرق، روابط همبستىى، نمايه گرمابى سليانينف، ضريب گياهى، ايران 


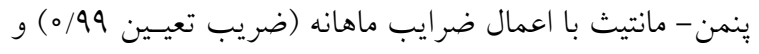

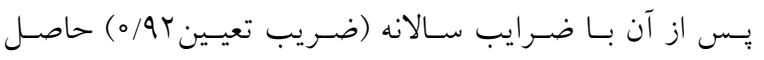

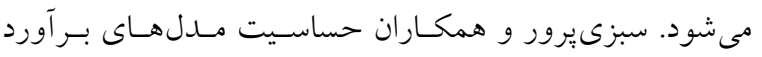

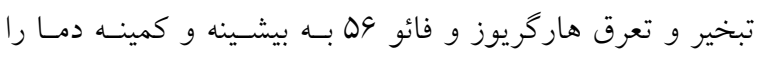

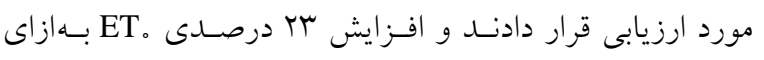

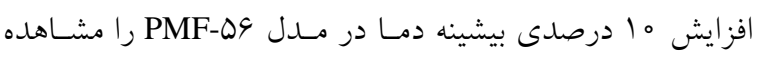

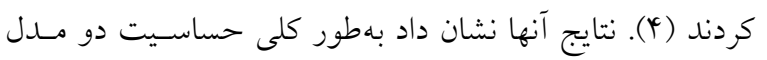

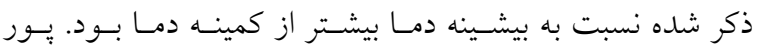

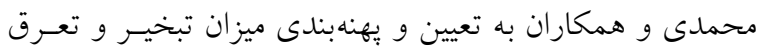

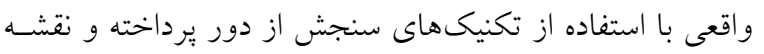
تبخير و تعرق واقعى يوششهاى مختلف سـطح حوضـهـ آبخيـز

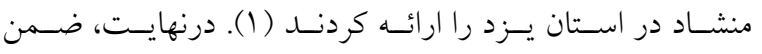
مشخص شدن تغييرات مكانى تبخير و تعرق صورت كرفتـه از

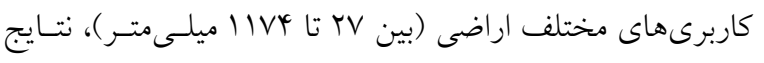

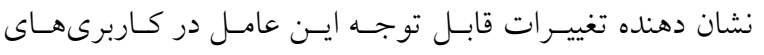

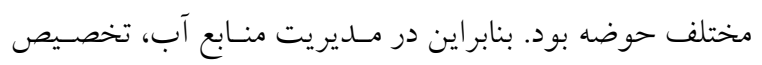

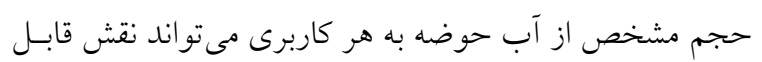
توجهى در صرفهجويى مصرف آب در كشاورزى داشـته باشـد.

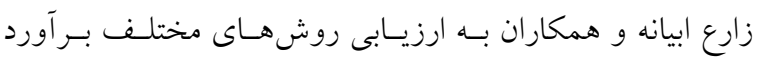

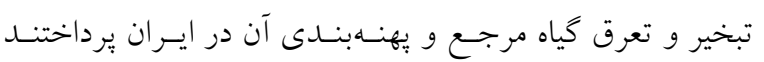

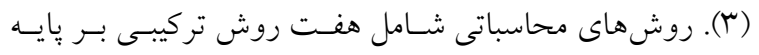

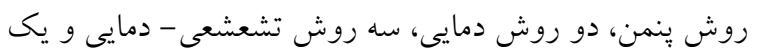

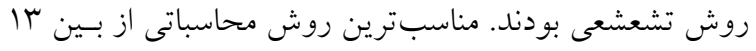
روش، در مقايسه با مقادير تبخيرو تعرق لايسيمترى در هر اقليم

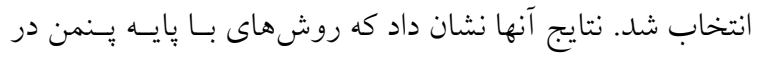

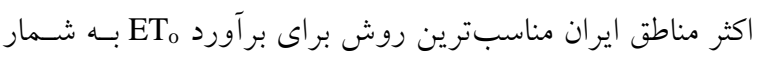

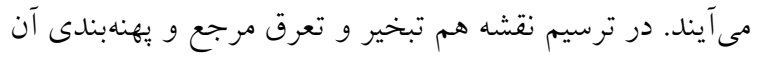

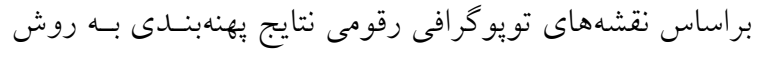
كريجينگ، نشان داد ميزان ET

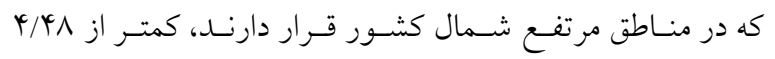

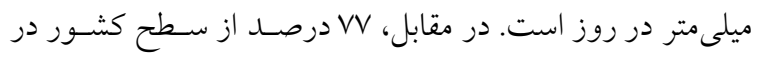

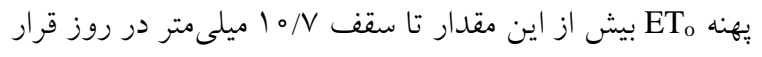

مقدمه - 20 - مقه بسيارى از نقاط جهان با كمبود آب روبرو هستند و با توجسه بـهـ

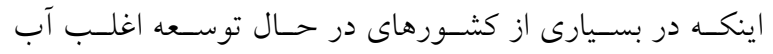
مصرفى در بخش كشاورزى بـــاى توليــ محصـول مـورد نيـاز

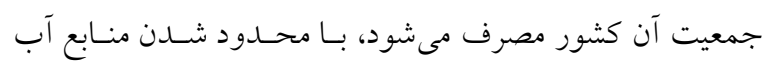
موضوع توليد محصولات كشاورزى مورد نياز جمعيت با همسين مقدار محدود آب از اهميت خاصى برخوردار است. كشور ايسران

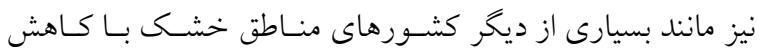
منابع آب براى تأمين مصارف مختلف بهويزٔه كشـاورزى مواجـهـ

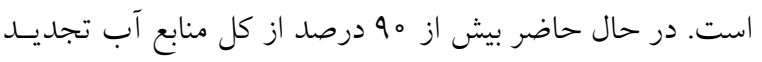

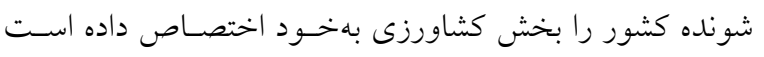

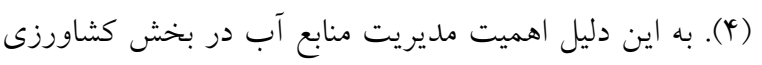

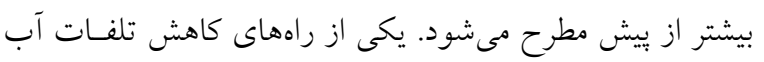

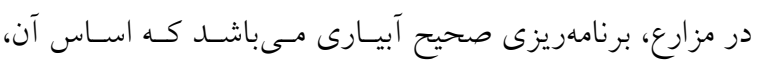

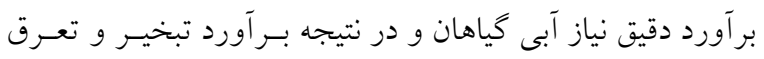

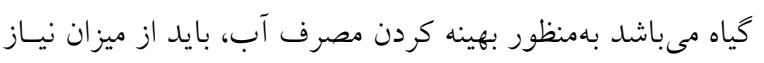

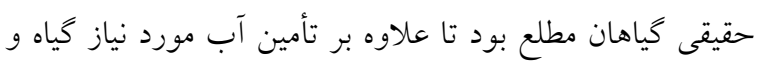

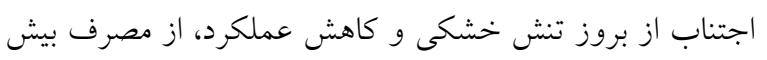

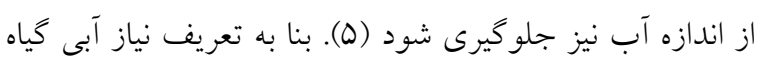

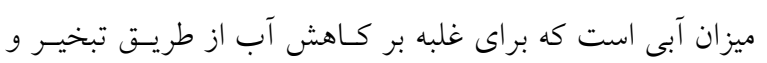
تعرق كافى باشد (9). تاكنون مطالعات بسيارى در زمينه تخمين تبخيـر و تعـرق و و باتس

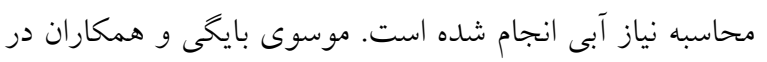

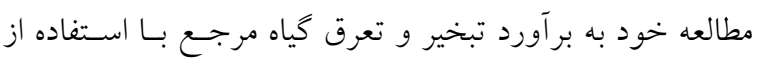

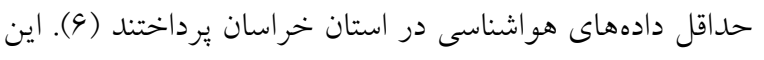

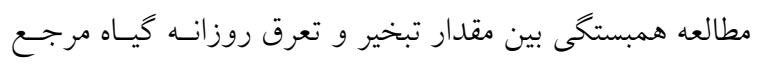

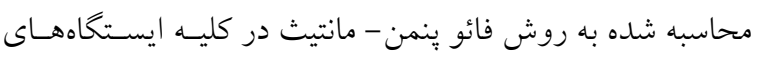

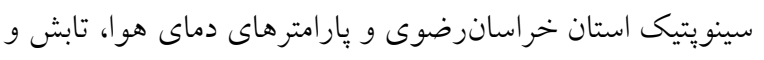

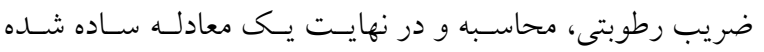

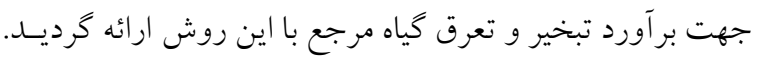

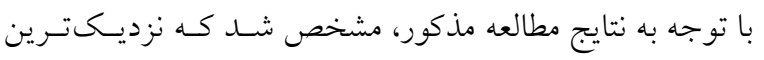
تخمينهاى انجام شده به دادههـاى لايسـيمترى از معادلـه فـائو 
آبى برخى محصولات منتخب، بهمنظور يافتن روابطى ساده بين

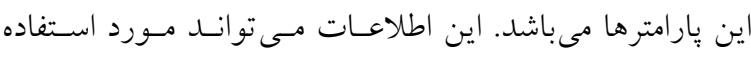

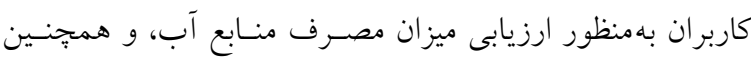

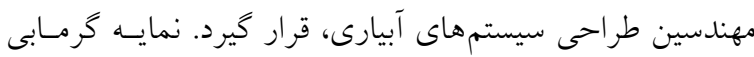

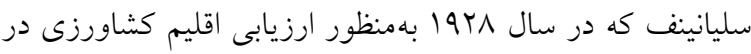
روسيه معرفى شد (Y)، از تقسيم ميانخين جمع بـارش سـالانه

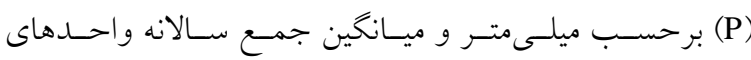

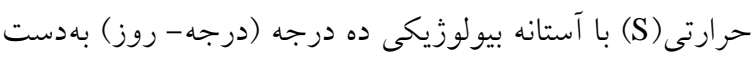

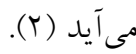

\section{مواد و روشها}

ايران كشور بهناورى است كه در محسدوده جفرافيـيى ro/r تـا V قرار گرفته است و از نظر اقليمى اغلب قسمت هاى آن در گروه اقليم خشك و نيمه خشك قرار دارند. ميـزان بـارش در كستـره

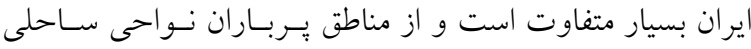

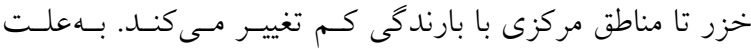
تفاوت بارش و عوامل مؤثر بر تبخير و تعرق در نواحى مختلف بهرت

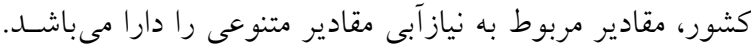

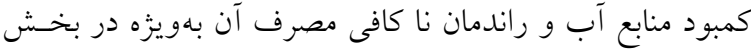
كشاورزى از جمله مشكلات در زمينه مصرف آب كشور اسـت. اين مطالعه بهمنظور ارائه روابطى ساده جهت بـرآورد نيـاز آبسى آبـ

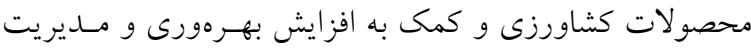

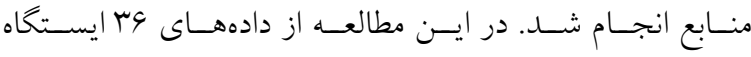

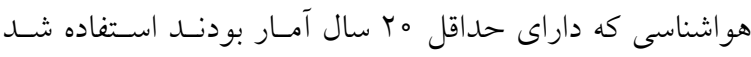
(شكل (). نمايه كرمابى سـليانينف، بـهـــورت نسـبت مقــادير

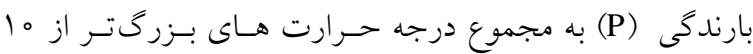
درجه سانتى گراد در طول دوره مورد برزسى (ماه، فصل يا سال) بهصورت زير معادله (1) تعريف مىشود (Y): $\mathrm{HTC}=\sum \mathrm{P}(\mathrm{mm}) / \sum \mathrm{T}\left({ }^{\circ} \mathrm{C}\right)$ forT $>10^{\circ} \mathrm{C}$ (1)

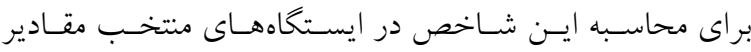

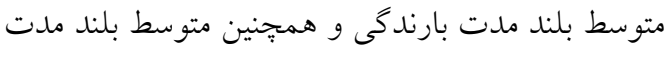

دارد. كَرومزا و همكاران اولين تقسيمبندى نواحى براساس نيـاز

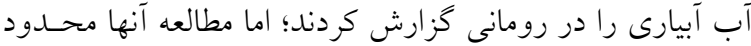

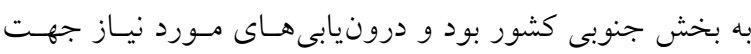

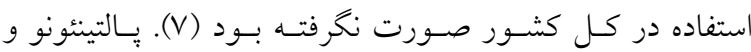

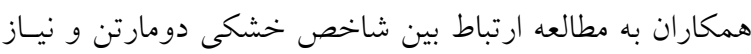

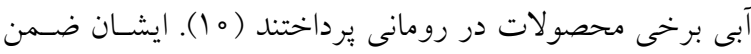

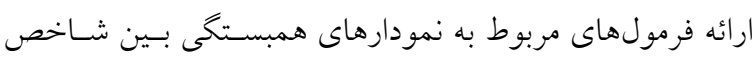

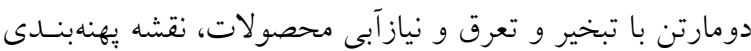

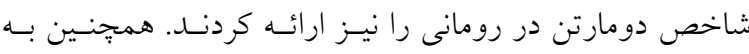

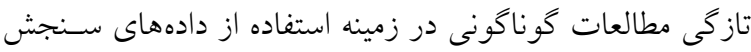
از دور بلويزه تصاوير ماهوارهاى در تخمين تبخيرو تعرق و نياز

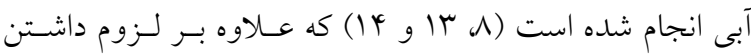

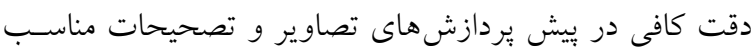

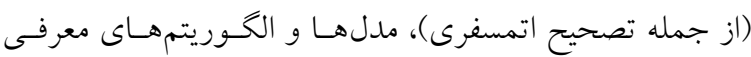
شده در اين زمينه نيز بايد در هـر منطقـه بـه درستى واسـنجى شوند. سبزى يرور و همكاران، در ايـران، بـهـ واسـنجى ضـرايب

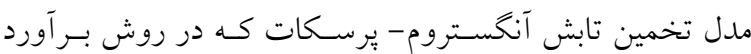
تبخير FAOD9 مورد استفاده قرار مى گيـرد، تيرداختنـد (9 و 11).

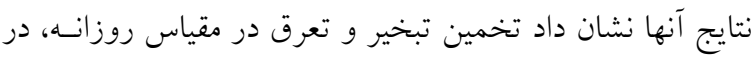
شرايطى كه از ضرايب واسنجى شـــه در منطقـهـ مـورد مطالعـهـ استقاده شود، VY ا بهبود مى يابد.

در ايران مناطقى وجود دارند كـه در آنها دادهــاى تـابش، سرعت باد و رطوبت هوا بــراى محاسـبه تبخيــر و تعـرق گيـاه

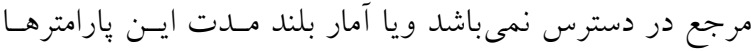
موجود نيست. لذا براى محاسبه نياز آبى، بسيارى از يارامترهاى مورد نياز تعيين تبخير و تعرق، تخمين زده مىشـوند. در ايسران هم تلاش هاى بسـيارى بــاى تخمسين بِارامترهـاى مـورد نيـاز

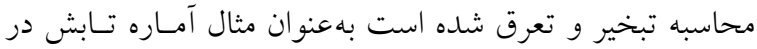
بسيارى از ايستاههاى ايران بهصورت محدود در دسترس است لترقاه

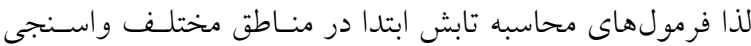

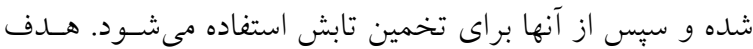
از اين مطالعه ايجاد همبستخى بين نمايه كرمابى سليانينف با نيار 


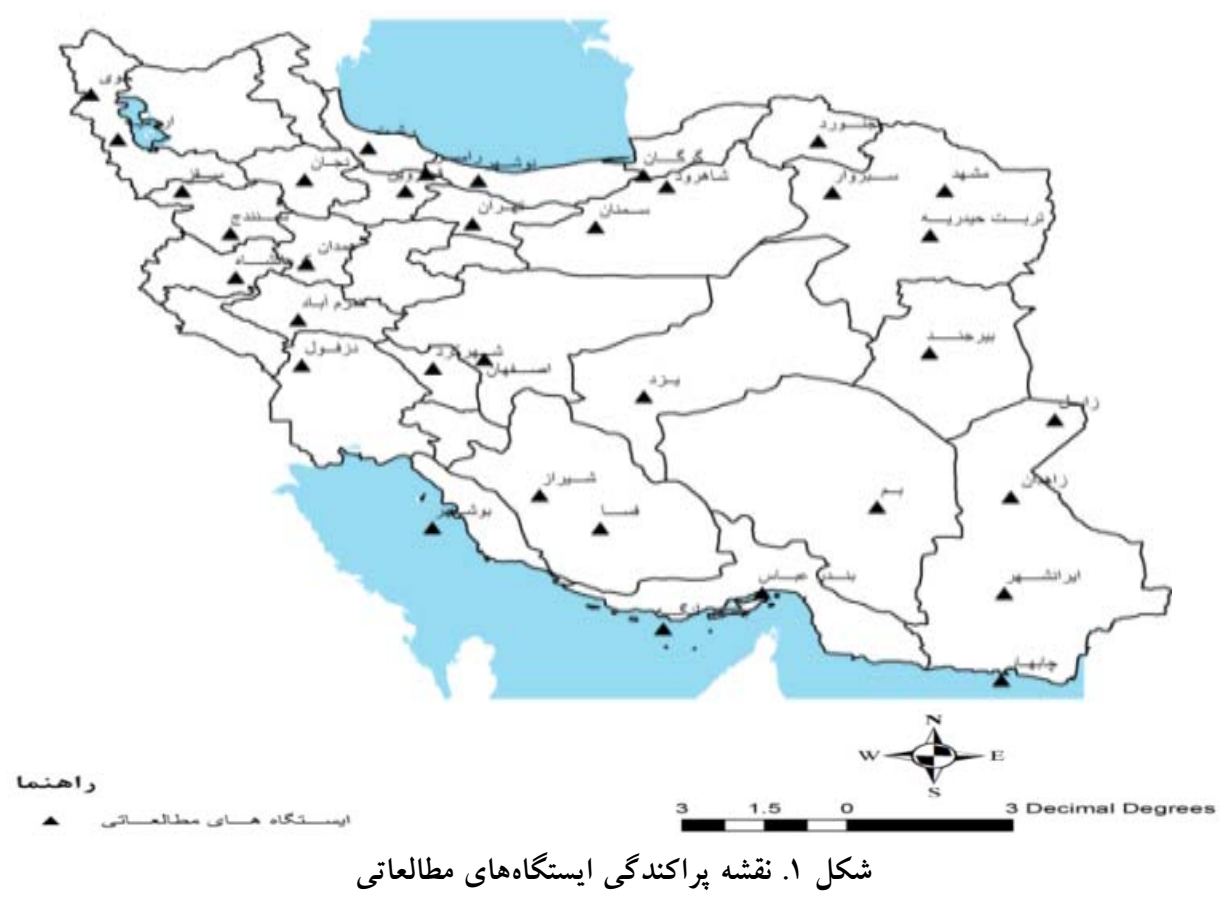

$\mathrm{KT}=\circ / \circ \circ \ln (\mathrm{TD})^{r}-\circ / \circ \mu r \mathrm{TD}+\circ / 4 \circ \mu r$

كه در آن:

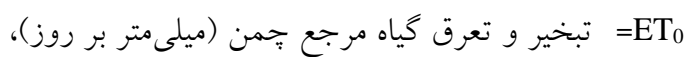

=TD تفاوت دماى حداكثر و حداقل روزانه (سانتى گراد)، =TC

Ra

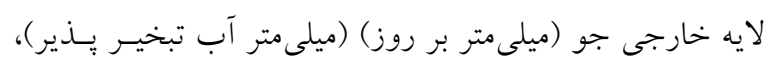

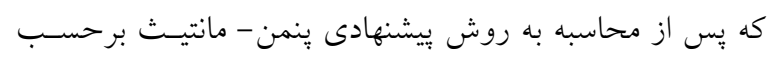

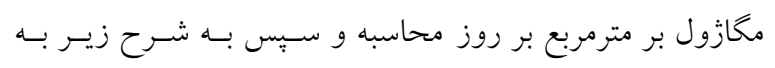

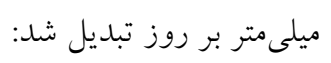

Equivalent - evaporation[mm.day $\left.{ }^{-1}\right]=\diamond / \uparrow \circ \wedge \times$ Radiation $\left[\mathrm{MJ} \cdot \mathrm{m}^{-r}\right.$.day $\left.{ }^{-1}\right]$

يك ضريب تجربى مىباشد كه تابش جهـانى و تفـاوت =KT

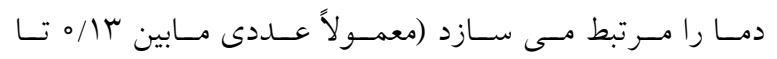
(19/19 محاسبه مى كردد).

درنهايت تبخير و تعرق يتانسيل با توجه به تبخيـر و تعـرق

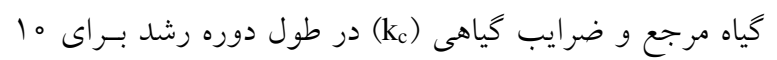
محصول نمونه محاسبه شد و مقادير نياز آبى بهعنوان تفاوت
مجموع دماى ميانكين روزانسه بـالاتر از ه ا درجـه سـانتى گـراد محاسبه شد و مقدار شاخص براى هـر ايستخاه در طـول دوره رشد گياه (طول دوره رشد براى هر كياه در هر ايستخاه متفاوت مىباشد و اين نكته در كليه محاسبات درنظر كرفته شده اسـت ) مورد بررسى بهدست آمد.

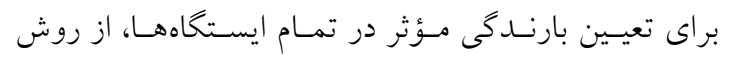

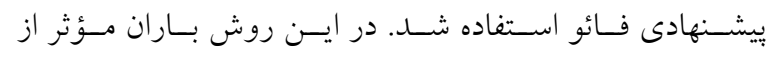
فرمولهاى زير محاسبه مىشود:

$\mathrm{P}_{\text {eff }}=\circ / 9 \times \mathrm{P}-1 \circ$ forP $\leq \mathrm{V} \cdot \mathrm{mm}$

$\mathrm{P}_{\mathrm{eff}}=\bullet / \wedge \times \mathrm{P}-\mathrm{r}$ forP $>\vee \cdot \mathrm{mm}$ كه درآن P و P به P برتيب مقدار كل بارندگى و مقدار بارنـدگى مؤثر برحسب ميلى متر مىباشند. براى محاسبه تبخير و تعرق از روش هارگريوز - سامانى بـا دوره ماهانه استفاده شد. در روش هارگريوز - سامانى بـهمنظـور محاسبه تبخير و تعرق يتانسيل فقط به دادههاى دما و تابش نياز

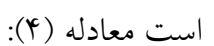
$\mathrm{ET}_{\circ}=\circ / \circ / r \Delta(\mathrm{KT})\left(\mathrm{R}_{\mathrm{a}}\right)(\mathrm{TD})^{\circ / \Delta}(\mathrm{TC}+\mathrm{v} / \wedge)$ 


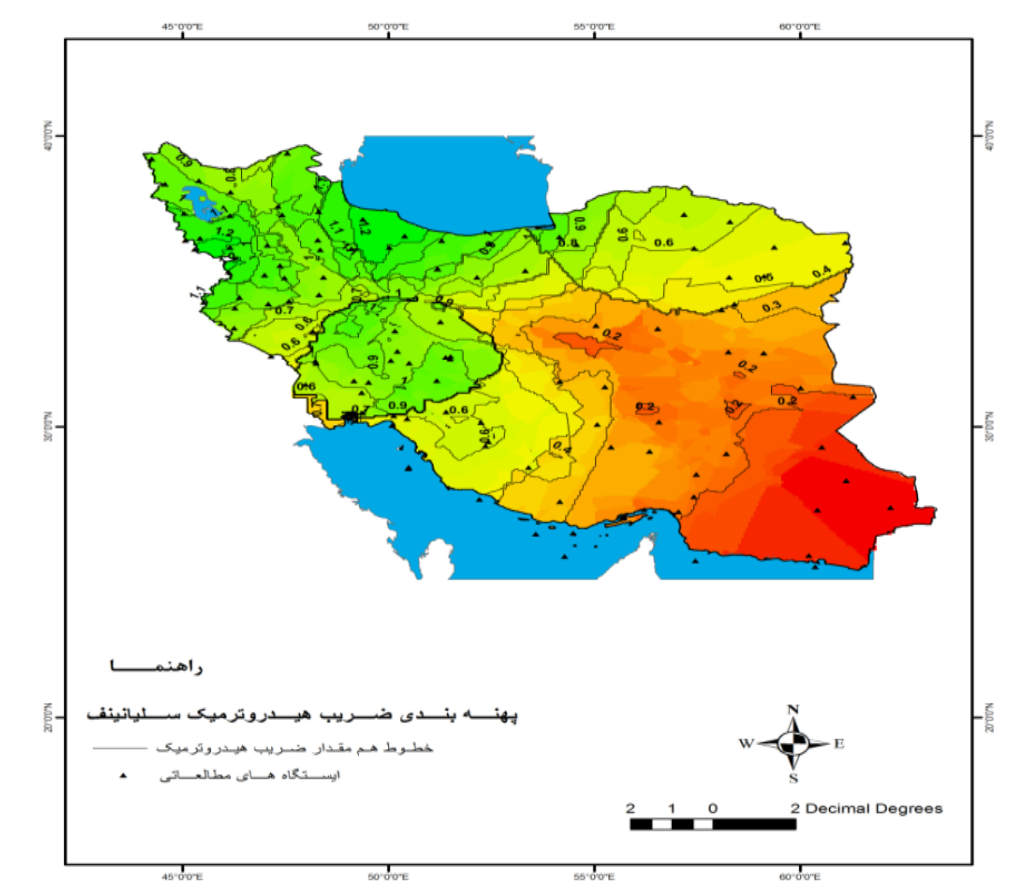

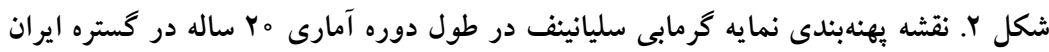

كه در آن Pقدار بر مقر آورد شده يا شبيهسـازى شــه، Q مقـادير مشاهداى و n تعداد نمونه ها مىباشد.

\section{نتايج و بحث}

در شكل (Y) خطوط هم مقدار نمايه سليانينف در كستره ايـران

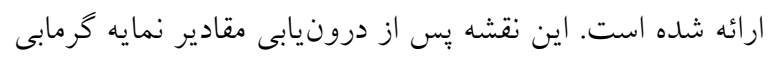

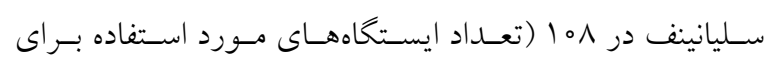

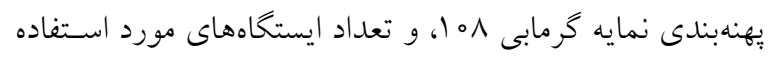

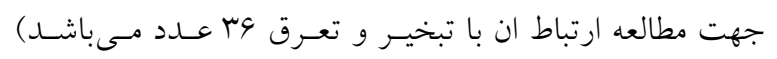

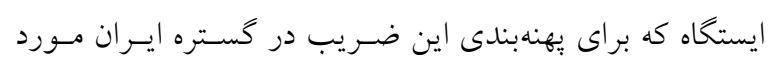

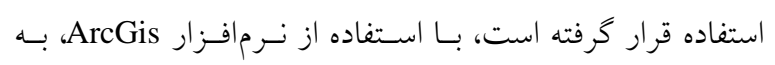

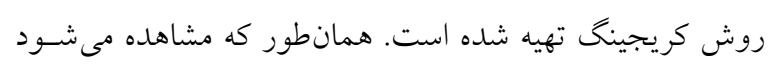

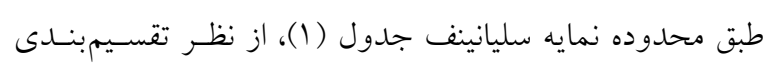

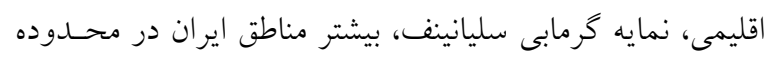

$$
\text { اقليمى خشك و نيمه خشك قرار دارند. }
$$

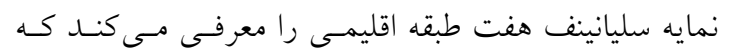

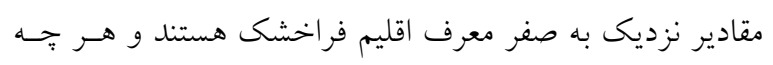

بارش مؤثر و ميزان تبخير و تعرق بهدست آمد كه در ادامه از آن

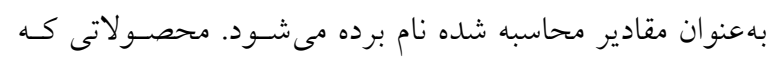

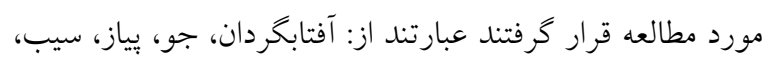

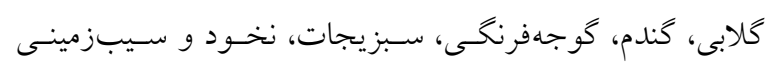

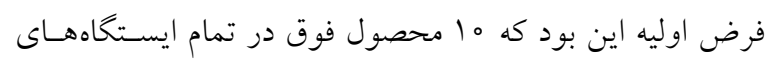

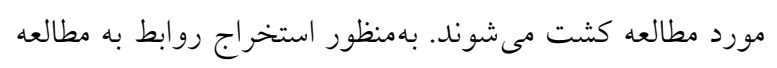

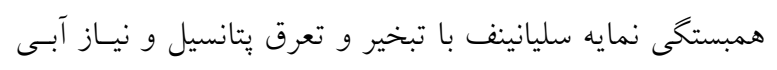
هر ما محصول نمونه در سطح كشور يرداخته شد.

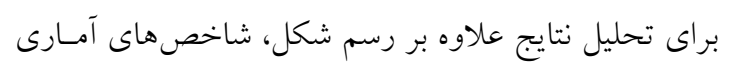

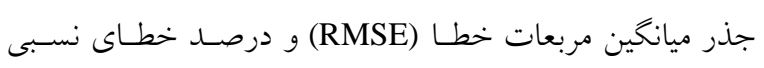

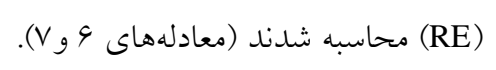
$\mathrm{RE}=\frac{\sum_{\mathrm{i}=1}^{\mathrm{n}}\left|\frac{\mathrm{Q}_{\mathrm{i}}-\mathrm{P}_{\mathrm{i}}}{\mathrm{Q}_{\mathrm{i}}}\right|}{\mathrm{n}} \times 100$
$\mathrm{RMSE}=\left[\frac{\sum_{\mathrm{i}=1}^{\mathrm{n}}\left(\mathrm{P}_{\mathrm{i}}-\mathrm{Q}_{\mathrm{i}}\right)^{r}}{\mathrm{n}}\right]^{0 / \Delta}$ 
نشر يه علوم آب و خاك (علوم و فنون كشاورزى و منابع طبيعى) / سال بيست و يك / شماره جهار / زمستان وها1

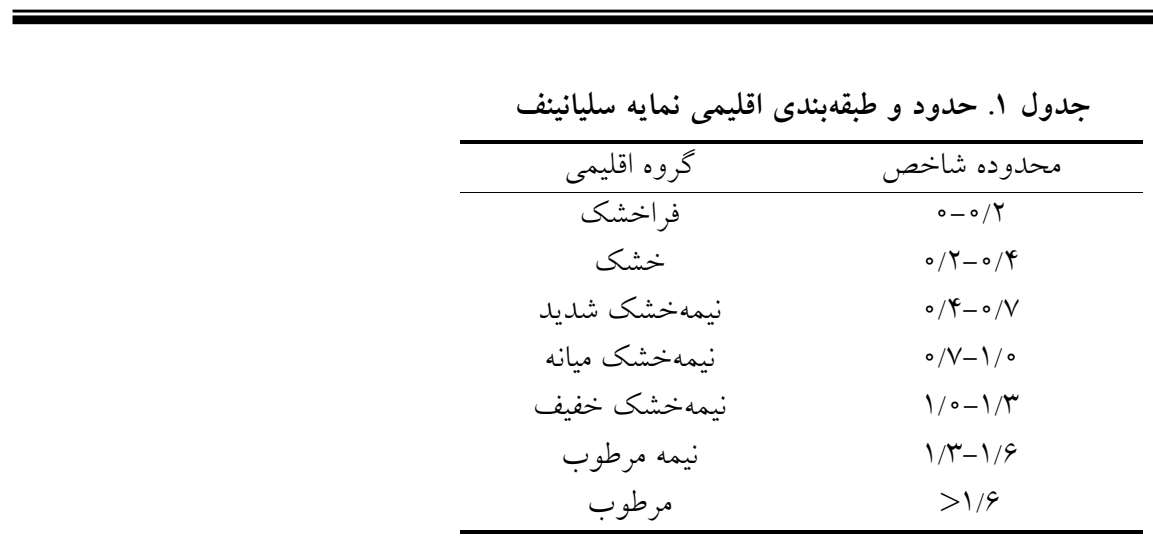

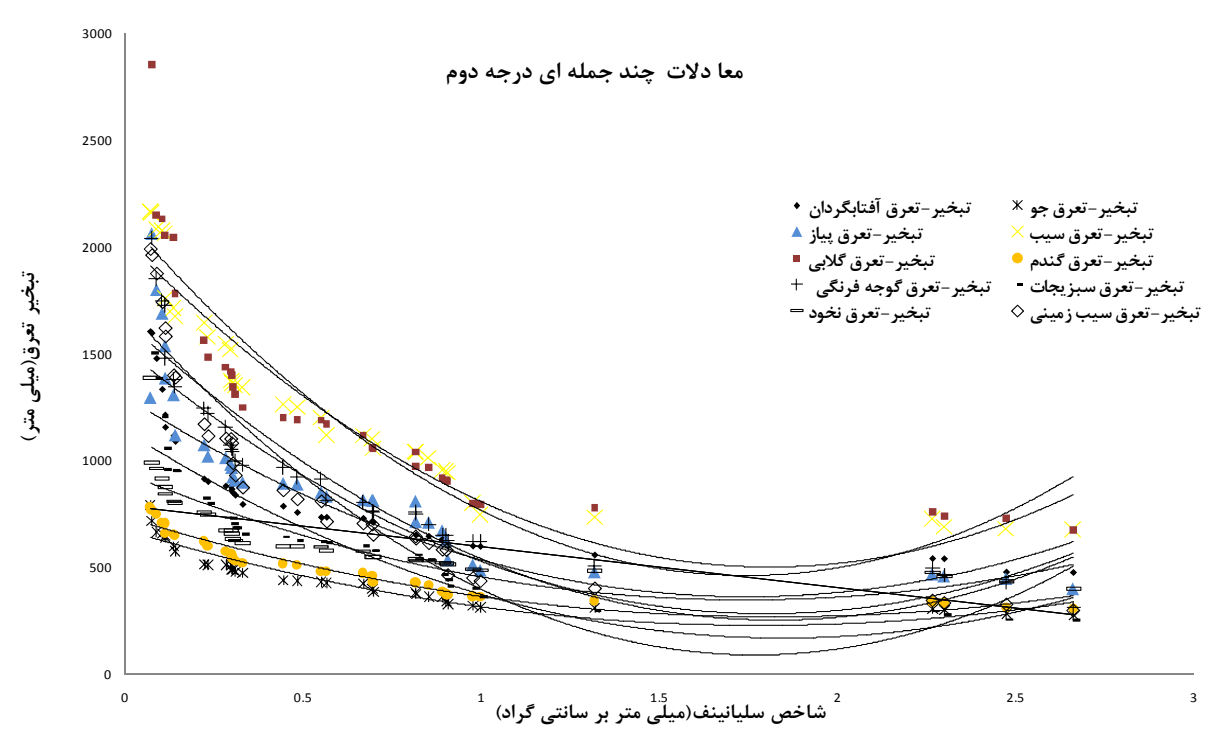

شكل r. تغييرات نمايه سليانينف با تبخير و تعرق كل هريك از محصولات در طول فصل رشد (معادلات جندجملهاى)

شاخص، كه علت آن مىتواند افزايش باران يا كاهش دما باشـد، مقادير تبخير و تعرق كـاهش مسىيابـد. پِارامترهـاى مربسوط بـــ معادلات شكل هاى (Y) و (Y) در جــدولهـاى (Y) و (Y) آورده شده است. همانطور كه از مقايسـه جــدول (1) و (Y) مشـاهده مىشود، ضريب تعيين معادلات رگرسيون جند جملـهاى درجـه.

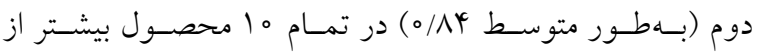
ضريب تعيين معادلات نمايى (بهطور متوسط رك/ه) اسـت كـه نشان مى دهد معادلات جند جملهاى، تغييرات مقـادير تبخيـر و تعرق را بهتر توجيه مى كنند. ضرايب تعيين معادلات استخراجى در اين تحقيق در مقايسه با مطالعه بالتينينو و همكـاران، مقـادير كمترى را دارا مىباشند. پِالتينينو و همكاران در بررسسى ارتبـاط تبخير و تعرق با شاخص دومارتن مقادير ضريب تعيين
مقدار اين شاخص از صفر فاصـله مسى گيـرد، از خشـكى اقلسيم

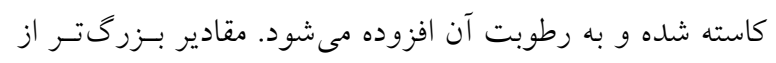
ب/ معرف اقليمهاى مرطوب هستند.

همبستخى بين نمايه سليانينف و تبخير و تعرق همبستخى هاى بين نمايه سليانينف و مقادير تبخيـر و تعـرق در طول فصل رشد براى محصولات مورد مطالعه، محاسـبه شـدند. در اين همبستكى مقادير نمايه سليانينف بهعنوان متغير مستقل و مقادير تبخير و تعرق بهعنوان متغير وابسته درنظر كرفته شـدند. طبق نتايج حاصله معادلات ركرسيونى جند جملهاى درجه دوم و نمايى معكوس و قوى، بين يارامترهاى همبسته مشـاهده شــ (شكل r و ؟Y). همانطور كه مشاهده مىشود با افـزايش مقـادير 


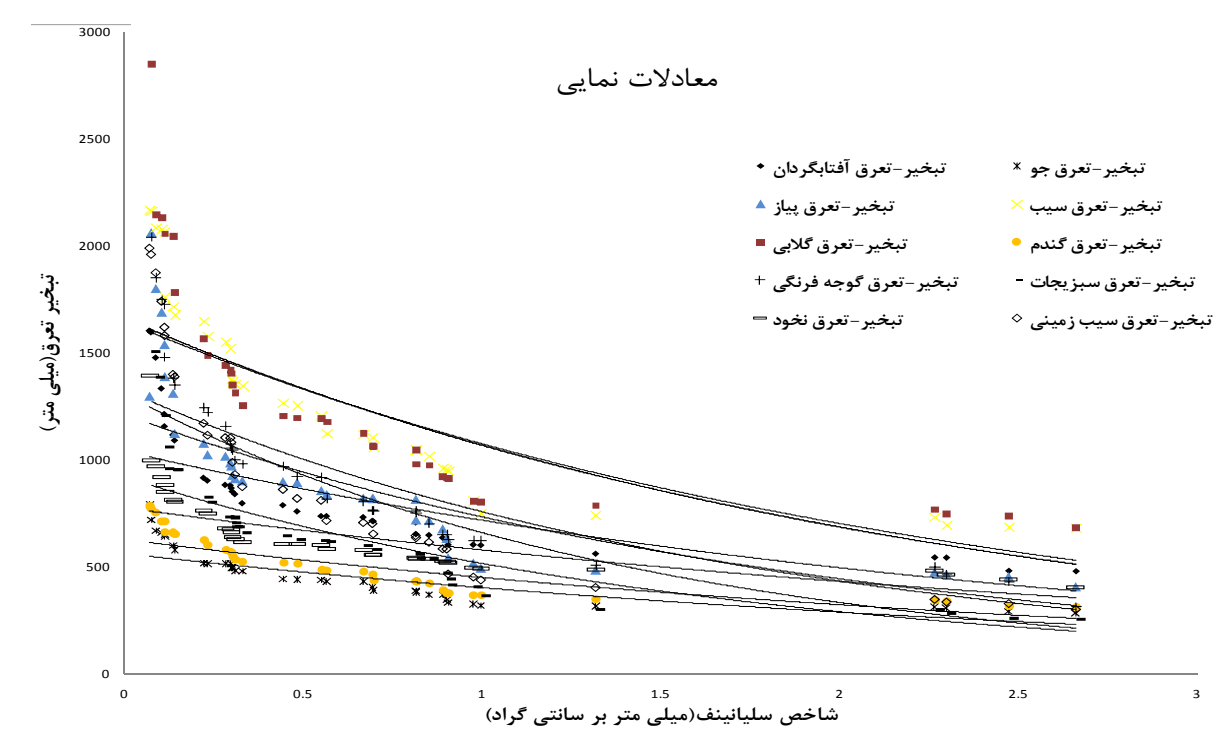

شكل ٪. تغييرات نمايه سليانينف با تبخير و تعرق كل هريك از محصولات در طول فصل رشد (معادلات نمايى)

\begin{tabular}{|c|c|c|c|c|}
\hline \multicolumn{5}{|c|}{ معادلات جندجملهاى } \\
\hline $\mathrm{R}^{r}$ & c & b & a & نام محصول \\
\hline o/VAr & 1ro。 & $-1 \circ V$ & $r \circ v / l$ & آفتابخر دان \\
\hline$\circ / 194$ & $9 V \pi / T$ & $-490 / 4$ & $1 r N / q$ & جو \\
\hline$\circ / \mathrm{NA \Lambda}$ & DOTK & $-1 \mu v \theta$ & $r N 1 / 9$ & ي بياز \\
\hline.$/ 911$ & rorq & -1911 & $499 / 1$ & سيب \\
\hline - NATQ & TITY & -1911 & $\Delta \Delta \circ / T$ & كَلابى \\
\hline.$/ 9 \pi \mathrm{V}$ & $V r \Delta / s$ & $-011 / \wedge$ & $\mid x \circ / 4$ & 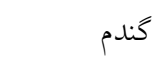 \\
\hline - /AOV & 1909 & - IOHV & $F r \mid / r$ & كو جهافرنكى \\
\hline$\circ / \Lambda \mid \wedge$ & $11{ }^{\prime}$ & $-104 \wedge$ & $r \wedge r / q$ & سبزيجات \\
\hline $0 / 210$ & $9 K r / 1$ & $-9 \wedge r / 0$ & $199 / \pi$ & نخود \\
\hline$\circ / M$ & IVIV & $-1 \Lambda \psi_{0}$ & $\Delta T \circ / \Delta$ & سيبزمينى \\
\hline
\end{tabular}

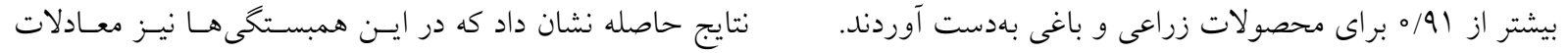

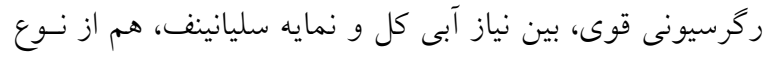

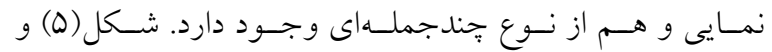
همبستخى بين نمايه سليانينف و نياز آبى

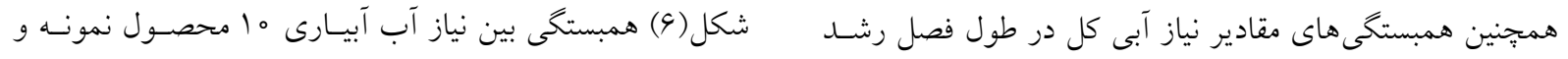

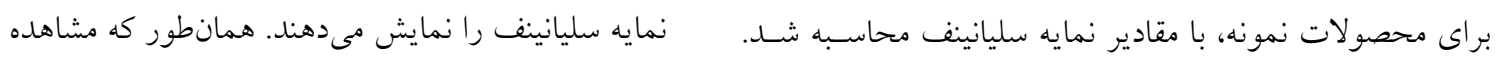


نشر يه علوم آب و خاك (علوم و فنون كشاورزى و منابع طبيعى) / سال بيست و يك / شماره جهار / زمستان وهـ1

جدول r. آمارههاى معادلات ركرسيونى نمايى تبخير و تعرق گياه و ضرايب سليانينف

\begin{tabular}{|c|c|c|c|}
\hline \multicolumn{4}{|c|}{ y=a*e معادلات نمايى } \\
\hline $\mathrm{R}^{r}$ & $\mathrm{~b}$ & $\mathrm{a}$ & نام محصول \\
\hline $0 / 94 V$ & $-o / \mu V$ & lorv & آفتابخر دان \\
\hline $0 / V 01$ & ג ג & $\Delta \Delta Q / V$ & جو \\
\hline.$/ 219$ & $-0 / 0$ & $|r| \circ$ & يياز \\
\hline - VQD & $-0 / 4 y$ & 1991 & سيب \\
\hline $0 / 999$ & $-0 / 4 Y$ & $194 \mathrm{~F}$ & كابلى \\
\hline o/var & س & $G K Y / T$ & كندم \\
\hline$\circ / V 9 V$ & $-\circ / \Delta \varphi$ & IrTs & كوجهفرنكى \\
\hline $0 / \wedge 01$ & $-0 / 0 \Lambda$ & $919 / 9$ & سبزيجات \\
\hline.$/ 094$ & $-0 / 49$ & $V V Y / V$ & نخود \\
\hline$\circ / V \wedge \Delta$ & $-0 / 99$ & $1 r \circ q$ & سيبزمينى \\
\hline
\end{tabular}

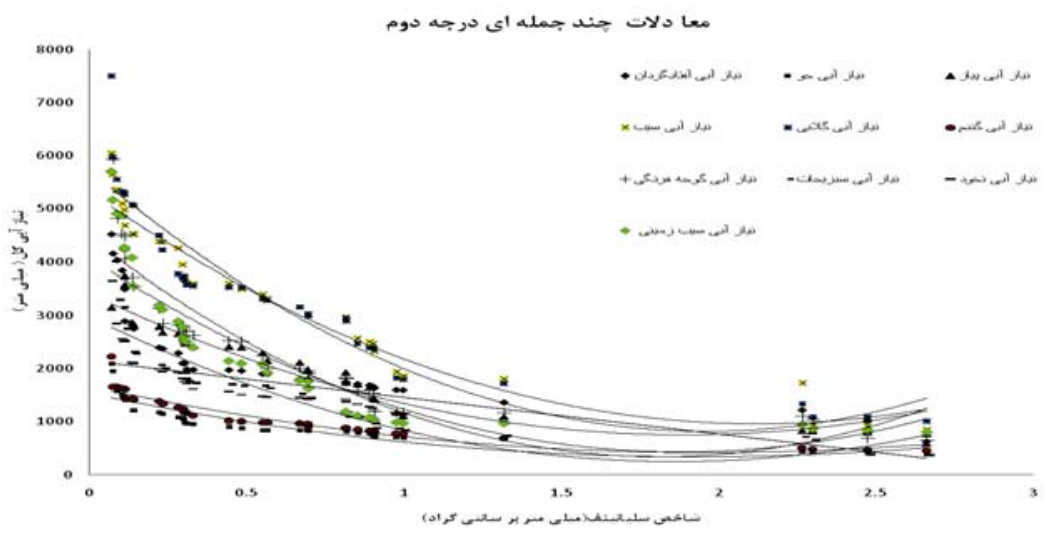

شكل ه. تغييرات نمايه سليانينف با نياز آبى كل هر يك از محصولات در طول فصل رشد (معادلات جند جملهاى درجه دوم)

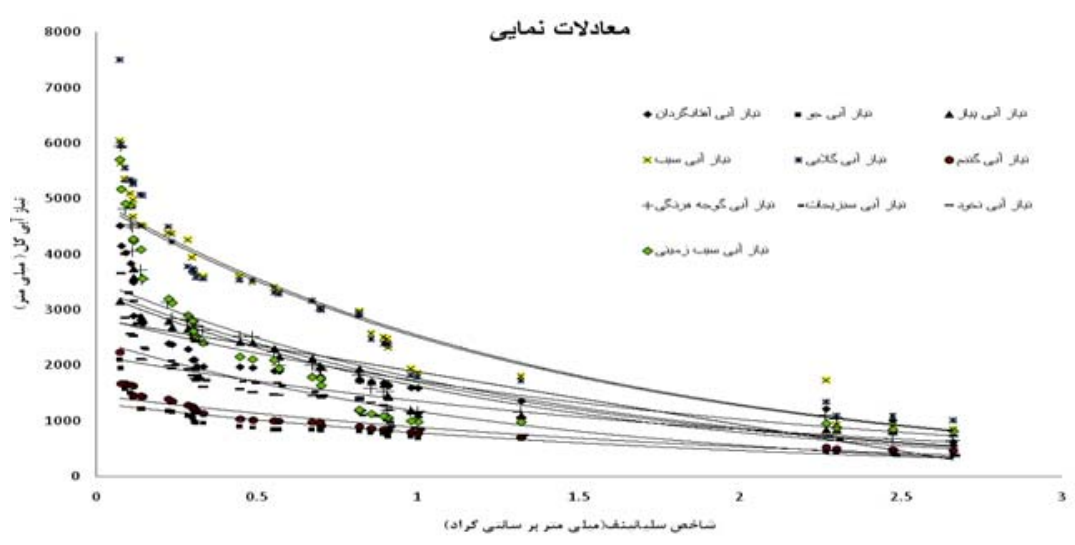

شكل 9. تغييرات نمايه سليانينف با نياز آبى كل هر يك از محصولات در طول فصل رشد (معادلات نمايى) 
همبستخى نمايه كرمابى سليانينف با نرخ تبخير و تعرق نياز آبى برخى محصولات ...

\begin{tabular}{|c|c|c|c|}
\hline \multicolumn{4}{|c|}{ جدول \&. آمارههاى معادلات رگرسيونى نمايى نياز آبى گياه و ضرايب سليانينف } \\
\hline \multicolumn{4}{|c|}{ معادلات نمايى } \\
\hline $\mathrm{R}^{\mathrm{r}}$ & $\mathrm{b}$ & $\mathrm{a}$ & نام محصول \\
\hline$\circ / \mathrm{VV}$ & $-0 / 0$ & rAYq & آفتابيخردان \\
\hline ०/Ar & $-0 / 01$ & ITIT & جو \\
\hline ०/Ar & $-0 / 99$ & MVQ & ي بياز \\
\hline.$/ 94$ & $-0 / 91$ & pqrq & سيب \\
\hline$\circ / 19$ & $-0 / 91$ & 0.19 & كالابى \\
\hline$\circ / \Lambda \mathrm{V}$ & $-0 / 0$ & 1490 & كَندم \\
\hline$\circ / \Lambda 1$ & $-0 / 99$ & TOTS & كو جه \\
\hline o/AY & $-\circ / N r$ & TEYA & سبزيجات \\
\hline$\circ / \Lambda \circ$ & 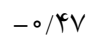 & rIVT & نخود \\
\hline $0 / 91$ & $-\circ / V Y$ & אוM & سيبزمينى \\
\hline
\end{tabular}

\begin{tabular}{|c|c|c|c|c|}
\hline \multicolumn{5}{|c|}{ معادلات جند جملهاى } \\
\hline $\mathrm{R}^{r}$ & c & $\mathrm{b}$ & $\mathrm{a}$ & نام محصول \\
\hline$\circ / N$ & mal & $-r V V \wedge$ & $V M T / 9$ & آفتابخردان \\
\hline$\circ / V \Lambda$ & IOTD & $-I T T V$ & rIV/4 & جو \\
\hline$\circ / V^{k}$ & 4090 & -rNFY & 1019 & يياز \\
\hline.$/ 94$ & סTH。 & $-4 \| \pi$ & $99 \mathrm{~V} / 9$ & سيب \\
\hline$\circ / 19$ & DVGY & $-Q \circ \varphi \circ$ & $I Y \wedge D$ & كابتى \\
\hline$\cdot / M$ & $19 \mathrm{VA}$ & $-I Y \wedge V$ & TTV/D & كُندم \\
\hline$\circ / \wedge \Delta$ & FYOT & - Yort & IrYq & كوجه فرنگى \\
\hline - $/ \Lambda t$ & rQSV & -rqV & vVq & سبزيجات \\
\hline$\circ / \wedge 。$ & ro99 & $-r \circ V Y^{r}$ & Drq & نخود \\
\hline$\circ / 19$ & FVY。 & $-\Delta \varphi \circ Y$ & $194 \mathrm{~V}$ & سيبزمينى \\
\hline
\end{tabular}

سوم بيان كردند كه احتمالاً افزايش درجه معادلات بـه افزايش

ضرايب تعيين منجر شده است.

صحت سنجى معادلات

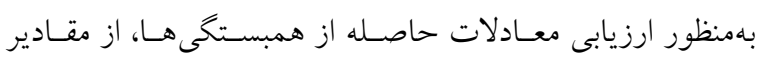

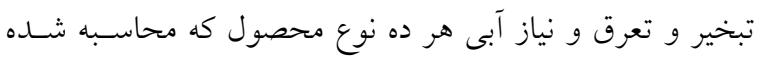

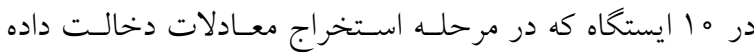

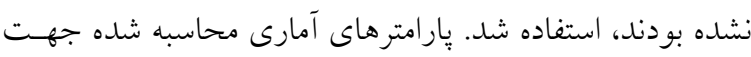
ارزيابى معادلات در جدول (9) ارائه شده است. با توجه به جدول (9) مشاهده مىشـود كـه عليـرغم اينكـهـ
مى شود در مورد همبستخى نمايه سليانينف با نياز آبسى متوسطط

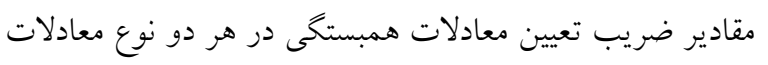

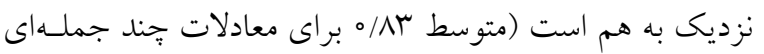

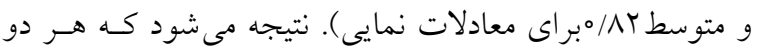
نوع معادله بيشتر از م^ درصد تغييرات مقادير نياز آبى را توجيه

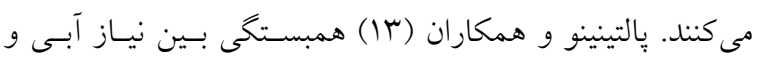

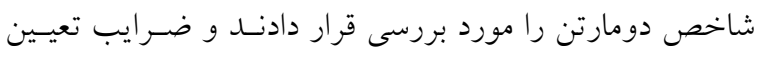

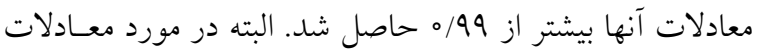

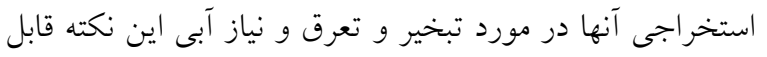

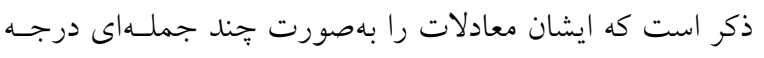


نشر يه علوم آب و خاك (علوم و فنون كشاورزى و منابع طبيعى) / سال بيست و يك / شماره جهار / زمستان وهـ1|

\begin{tabular}{|c|c|c|c|}
\hline \multicolumn{4}{|c|}{ جدول צ. يارامترهاى آمارى حاصل از ارزيابى معادلات رگرسيونى } \\
\hline جذر ميانخين مربعات خطا (ميلىمتر) & درصد خطاى نسبى ٪\% & نوع معادله & نام محصول \\
\hline$r 11 / r$ & $10 / 0$ & نمايى & آف-آر> \\
\hline$\Delta V \backslash / \Gamma$ & $r Y / l$ & جند جملهاى & \\
\hline$r \times q / D$ & $r 1 / 9$ & 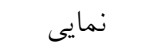 & \\
\hline$M / M / 9$ & $1 \circ Y / \Lambda$ & جند جملهاى & . \\
\hline$\Delta \wedge \mu / \Delta$ & $\varphi \circ / V$ & نمايى & \\
\hline$V T Y / T$ & $\uparrow N / 9$ & جند جملهاى & \\
\hline $1 \circ Y 4$ & rN/l & نمايى & \\
\hline Irtso & 4 & جند جملهاى & \\
\hline$\vee 11$ & ry & نمايى & $y \leqslant$ \\
\hline$\Lambda \leftarrow Q / 9$ & Tr/V & جند جملهاى & \\
\hline$r M d /$ & $r M / 1$ & نمايى & ₹ \\
\hline YYN/T & re/9 & جند جملهاى & \\
\hline $99 \mathrm{~V} / 9$ & $09 / 1$ & نمايى & \\
\hline$\vee \backslash \wedge$ & $\wedge 1$ & جند جملهاى & \\
\hline rAV/A & $99 / 0$ & نمايى & \\
\hline$|\Lambda T| / r$ & $r \circ r / 9$ & جند جملهاى & \\
\hline$\varphi \wedge \mu / \mathcal{Y}$ & ry & ن تمايى & \\
\hline$\Delta R T / T$ & 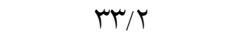 & جند جملهاى & J \\
\hline $0 \circ 4 / 9$ & $9 r / 1 r$ & نمايى & \\
\hline $9 r 8 / 9$ & $\mid r N / 9$ & جندل جملهاى & \\
\hline
\end{tabular}

مىرسد معادلات نمايى داراى خطاى نسبى بـهـ مراتـب كمتـرى نسبت به معادلات جند جملهاى هستند. همجنـسين در معـادلات

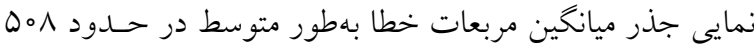
ميلى متر است كه اين شاخص در مورد معادلات جنـد جملـهاى بهطور متوسط مام ميلى متر مىباشد كه اين مقايسـه هــم نشـان مى دهد معادلات نمايى به مراتب مناسبتر مىباشند. در مطالعـه يالتينينو و همكاران (0 (1)، در مورد تبخير و تعـرق طـول فصـل رشد، بيشترين اختلاف براى ذرت در حدود بوأ1 ميلىمتر و در

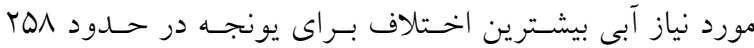

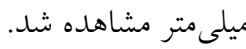

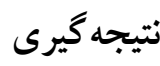

هدف از اين مطالعه استخراج روابطى ساده از همبسـتخىهـاى
معادلات همبستكى مربوط به معادلات جند متغيـره درجـه دوم هم در مورد تبخير و تعرق و هم نياز آبى، داراى ضريب تعيـين بيشترى نسبت به معادلات نمايى بودند اما مقدار نيـاز آبسى كـه. توسط معـادلات جنــد جملـهاى بــرآورد شــده اسـت اخـتلاف بيشترى با مقادير واقعى در مقايسـه بــا مقــادير بــــآورد شــده از معادلات نمايى دارند. در معادلات نمايى بيشترين درصد خطاى نسبى در حدود 9 درصد مربوط به سيبزمينى مىباشـد و بـه غير از آن به نظر مىرسد براى ديخر محصولات درصـد خطـاى

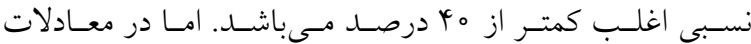

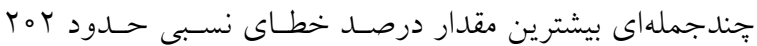
درصد مربوط به سبزيجات است كه نشان دهنــده تفـاوت زيـاد مقادير محاسبه شده و برآورد شده مى باشد. هـر جنـــد در سـاير محصولات اين اختلافات كمتر اسـت امـا در مجمـوع بـه نظـر 
قابل قبولى هم در مورد تبخير و تعرق و هم نيـازآبى مشـاهده

شد، اما اختلاف قابـل تـوجهى بـين مقـادير محاسـبه شــده و

برآورد شده ديلده مىشـود كـه ممكـن اسـت اسـتفاده از ايسن

معادلات رازير سوال ببرد. اين اختلافات زيـاد ممكـن اسـت

بهعلت استفاده از يكى معادله بــراى كـل ايسـتخاههــاى كشـور

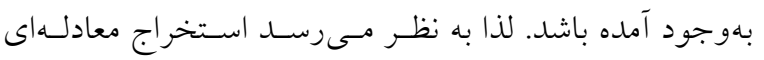

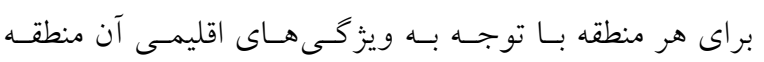

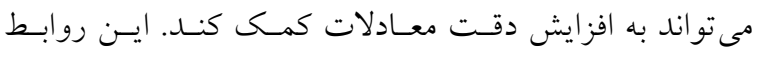
مى تواند به طراحسان سيسـمهـــاى آبيـارى و برنامسهريـزان در برآورد مقادير نياز آبى محصول (CWR) بـا اسـتفاده از نمايسه سليانينف و ارزيابى منابع آب در مناطق و اقليمهايى مثل ايران

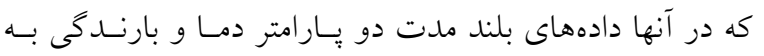
سهولت در دسترس مىباشند، كمك كند.
بين مقادير نيازآبى و تبخير و تعرق يتانسيل گياهـان زراعى و

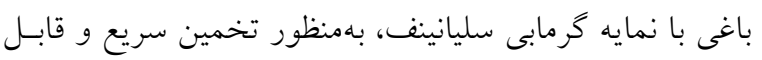
قبول نياز آبى براى استفاده در مـديريت منـابع آب بـهـويـزّه در مناطقى كه در آنها پارامترهاى مورد نيـاز جهــت محاسـبه نيـاز

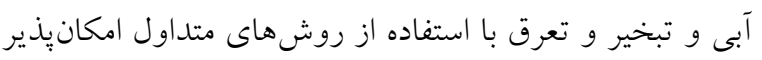
نيست، بود. نتايج نشان دهنده معادلات نمايى و جند جملـهاى درجه دوم قوى بين پيار امترهاى همبسته بود. ميـانخين ضـريب

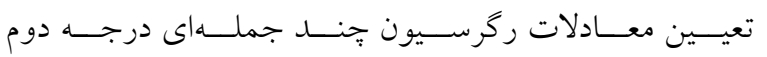

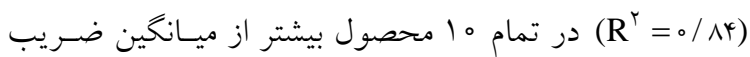
تعيين معادلات نمايى (Rr) مى دهد در معادلات جنات جملهاى، نمايه سـليانينف، تغييـرات مقادير تبخير و تعرق را بهتـر توجيـه مسى كنــد. هـر جنـــ در معادلات حاصل شده از همبستخى هـا مقـادير ضـريب تعيـين

منابع مورد استفاده

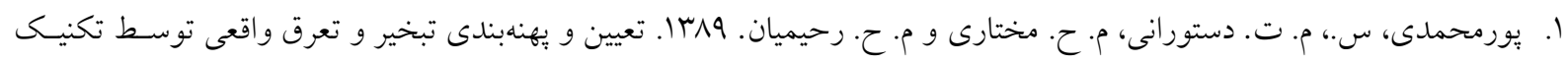
سنجش از دور و الكوريتم سبال (مطالعه موردى: حوزه آبخيز منشاد در استان يزد). مجله علوم و مهندسى آبخيـزدارى ايسران سا:

r) r r

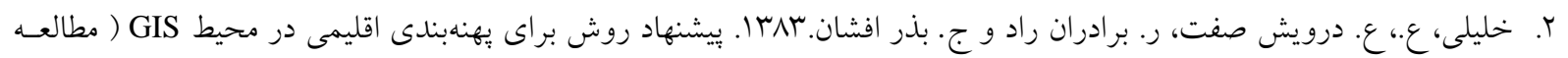
موردى: شمال غرب ايران). مجله بيابان و(Y):

س. زارع ابيانه، ح.، م. بيات وركشى، ع. الف. سبزى يرور، ص. معروفى وع. قاسمى.

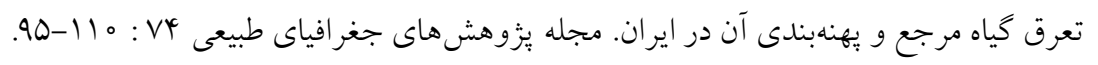

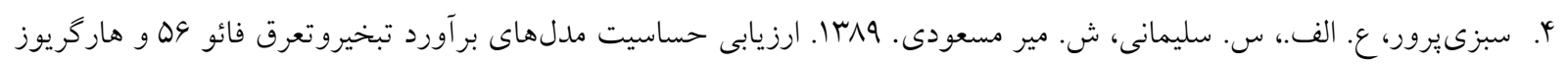

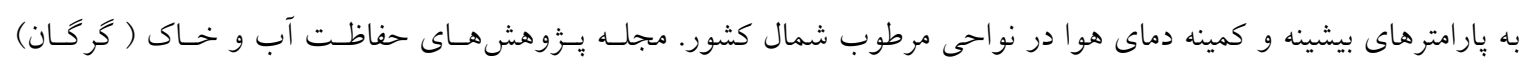
$.1-Y Y:(r) I V$

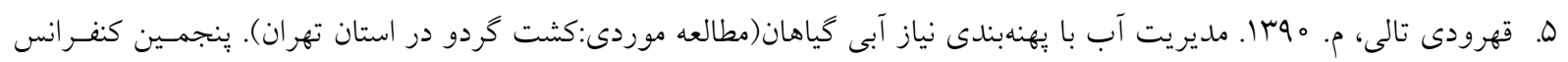
سراسرى آبخيزدارى و مديريت منابع آب و خاى كشور. كرمان . انجمن مهندسى آبيارى و آب ايران. اسفندهوسا.

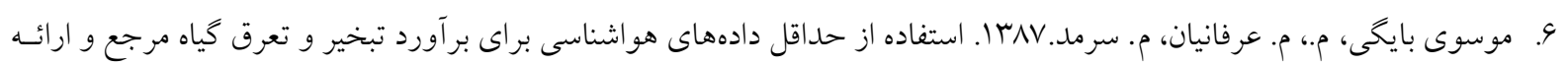

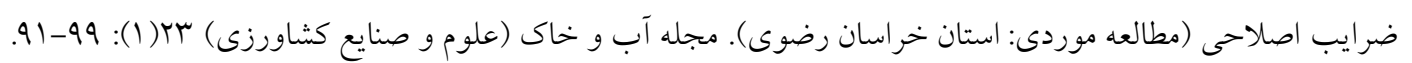

7. Grumeza, N. and Cr. Kleps. 2005. Irrigation designs in Romania. Ed. Ceres, Bucharest, Romania.

8. Kustas, W. P., J. M. Norman. 2009. Use of remote sensing for evapotranspiration monitoring over land surfaces. J. Hydrological Sci. 41: 495-516.

9. Mousavi, R., A. A. Sabziparvar, S. Marofi, N. A. Ebrahimi and M. Heydari. 2013. Calibration of the angstromprescott solar radiation model for accurate estimation of reference evapotranspiration in the absence of observed 
solar radiation. Theor. Appl. Climatol. 119: 43-54.

10. Paltineanu, N., E. Tanasescu and I. F. Mihailescu. 2006. Relationships between the DeMartone aridity index and water requirements of some representative crops: A case study from Romania. Int. Agrophysics 21: 81-93.

11. Sabziparvar, A. A., R. Mousavi, S. Marofi, N. A. Ebrahimi and M. Heydari.2013. An improved estimation of the angstrom-prescott radiation coefficients for the FAO56 penman-monteith evapotranspiration method. Water Resour. Manage. 27: 2839-2854 .

12. Selianinov, G. T. 1928. On agricultural climate valuation (in Russian). Proc. Agric. Meteor. 20: 165-177.

13. Ray, S. S., V. k. Dadhwal. 2001. Estimation of crop evapotranspiration of irrigation command area using remote sensing and GIS, Agric. Water. Manage. 49: 239-249.

14. Zhang, l., R. Lemeur, J. P. Goutorbe. 1995. A one-layer resistance model for estimating regional evapotranspiration using remote sensing data. Agric. Forest. Meteorol. 77: 241-261. 


\title{
Correlation of Selianinov Hydrothermal Coefficient with Reference Evapotranspiration and Crop Water Requirement for Some Selected Crops and Different Weather Sites of Iran
}

\author{
A. A. Sabziparvar ${ }^{*}$, S. Ebrahimzadeh and M. Khodamoradpour ${ }^{1}$
}

(Received: May 26-2014; Accepted: April 16-2017)

\begin{abstract}
The most important factor in determining crop water requirement is estimation of evapotranspiration (ET). Majority of the methodsestimate ET apply series of relatively complex formula,which is then used to determine crop evapotranspiration (ETc). The parameters used in aforesaid methods are: Solar radiation, wind speed, humidity, etc. Unfortunately, in Iran and many countries, long-term records of these parameters are not readily available. The purpose of this study is to calculate the Selianinov Hydrothermic Index that merely requires daily temperature and precipitation data in order to determine correlation coefficients (r) versus ET and Crop Water Requirement (CWR) of some agricultural crops of Iran. First, the Selianinov index is calculated from daily precipitation and temperature during the growth season. Further, the results are correlated against both ETc and CWR. The model results indicate inverse (negative) strong exponential and polynomial relations between the dependent and independent variables. Coefficient of determination (R2) for polynomial equations (on average 0.84) in all crops was better than exponential equations (on average 0.72). Correlation between Selianinov index and CWR indicates that coefficient of determination in both equations was close together ( 0.83 for polynomial equations and 0.82 for exponential equations).
\end{abstract}

Keywords: Correlation equations, Crop coefficient, Crop water requirement, Evapotranspiration, Iran, Selianinov Hydrothermal Index.

1. Dept. of Water Eng., Faculty of Agric., Bu-ali Sina Univ., Hamedan. Iran.

*: Corresponding Author, Email: swsabzi@basu.ac.ir 